\title{
Analisis Penerapan Standar Akuntansi Pemerintah Berdasarkan PP No. 71 Tahun 2010 Pada Dinas Pekerjaan Umum Bina Marga dan Tata Ruang Provinsi Sumatera Selatan
}

\author{
Sri Hartati ${ }^{1}$, Edduar Hendri ${ }^{2}$, Emma Lilianti ${ }^{3}$ \\ ${ }^{1}$ Fakultas Ekonomi Universitas PGRI Palembang \\ ${ }^{2}$ Fakultas Ekonomi Universitas PGRI Palembang, hendri edduar@yahoo.com \\ ${ }^{3}$ Fakultas Ekonomi Universitas PGRI Palembang, emmaliliantiok@gmail.com
}

\begin{abstract}
The purpose of this study is to analyze the application of government accounting standards based on PP. 71 of 2010 At the Public Works Office of Bina Marga and Spatial Planning of South Sumatra Province which is analyzed through Financial Statements, Information Systems / Devices used and Organizational Commitment Performance time is to determine the obstacles in the Application of PP No.71 of 2010 concerning Accrual-Based Government Accounting Standards just implemented in 2018. This type of research is qualitative descriptive research. This research was conducted by taking an object at the Public Works Office of Bina Marga and Spatial Planning of South Sumatra Province, which is located at Jalan Ade Irma Nasution No. 10 Palembang. The types of data used in this study are primary data and secondary data. Methods of data analysis using descriptive analysis. Based on data analysis, the implementation of SAP Public Works Office of Highways and Spatial Planning of South Sumatra Province which is indicated by Commitment, Information Systems / Devices used is concluded that seen from the preparation of financial statements not based on PP. 71 Year 2010, the Information System / Tool used is SIMDA Version 2.7.7 which has been accrual based but still needs socialization in its application as well as Organizational Commitment that supports the accrual-based government regulation.
\end{abstract}

Keywords: Accrual Based SAP, Implementation of PP No. 71 of 2010

\begin{abstract}
ABSTRAK
Tujuan penelitian ini adalah untuk menganalisis Penerapan Standar Akuntansi Pemerintah Berdasarkan PP No. 71 Tahun 2010 Pada Dinas PU Bina Marga dan Tata Ruang Provinsi Sumatera Selatan yang dianalisis melalui Laporan Keuangan, Sistem Informasi/Perangkat yang digunakan dan Komitmen Organisasi.Time kinerja untuk mengetahui kendala dalam Penerapan PP No.71 Tahun 2010 tentang Standar Akuntansi Pemerintah Berbasis Akrual yang baru diterapkan pada tahun 2018. Jenis penelitian adalah penelitian deskriptif kualitatif. Penelitian ini dilakukan dengan mengambil objek pada Dinas PU Bina Marga dan Tata Ruang Provinsi Sumatera Selatan yang beralamat di Jalan Ade Irma Nasution No. 10 Palembang. Jenis data yang digunakan dalam penelitian ini adalah data primer dan data sekunder. Metode Analisis data menggunakan analisis deskriptif. Berdasarkan analisis data maka Penerapan SAP Dinas PU Bina Marga dan Tata Ruang Provinsi Sumatera Selatan yang diindikasikan dengan Komitmen, Sistem Informasi/Perangkat yang digunakan disimpulkan bahwa dilihat dari penyusunan laporan keuangan belum berdasarkan PP No. 71 Tahun 2010, Sistem Informasi/Perangkat yang digunakan adalah SIMDA Versi 2.7.7 yang telah berbasis akrual tetapi masih perlu untuk diadakan sosialisasi dalam penerapannya serta Komitmen Organisasi yang mendukung dengan adanya peraturan pemerintah berbasis akrual tersebut.
\end{abstract}

Kata Kunci : SAP Berbasis Akrual, Penerapan PP No. 71 Tahun 2010

\section{A. PENDAHULUAN}

Terciptanya good governance yang baik menjadi tuntutan masyarakat. Good governance adalah suatu sistem tata kelola organisasi untuk mengefektifkan, mengefisienkan, mengekonomiskan dan memproduktifkan pengelolaan sumber daya 
ekonomi dalam rangka pencapaiaan tujuan organisasi dengan prinsip keterbukaan dan pertanggungjawaban. Pemerintah harus memiliki sistem manajemen yang handal, serta kebijakan dan prosedur yang baik dengan dukungan manajemen personal yang baik. Sebuah kriteria yang bisa dipakai untuk mengukur derajat akuntabilitas publik adalah akuntabilitas pengelolaan keuangan negara oleh pemerintah. Efektivitas dan efisiensi kebijakan publik akan terefleksikan dari laporan keuangan pertanggungjawaban APBN/APBD. Transparansi berarti keterbukaan pemerintah dalam memberikan informasi yang terkait dengan aktifitas pengelolaan sumber daya publik kepada pihak-pihak yang membutuhkan informasi.

Pemerintah berkewajiban untuk memberikan informasi keuangan dan informasi lainnya yang akan di gunakan untuk pengambilan keputusan ekonomi, sosial, dan politik oleh pihak-pihak yang berkepentingan. Untuk mewujudkan pemerintahan yang transparan dan akuntabel sesuai dengan prinsip good governance dalam pengelolaan keuangan maka harus sesuai dengan Undang-Undang Nomor 17 Tahun 2003 tentang Keuangan Negara, Undang-Undang Nomor 1 Tahun 2004 tentang Perbendaharaan Negara dan Undang-Undang Nomor 15 Tahun 2004 tentang Pengawasan dan Pertanggungjawaban Keuangan Negara yang memayungi pengelolaan keuangan negara maupun keuangan daerah.

Menurut PP Nomor 71 Tahun 2010, Standar Akuntansi Pemerintah (SAP) harus diaplikasikan untuk penyusunan laporan keuangan tahun anggaran 2010. Artinya bahwa penyajian laporan keuangan tahun 2010 sudah harus sesuai dengan SAP. Penyusunan laporan keuangan yang berpedoman pada Standar Akuntansi Pemerintahan bermanfaat untuk pemenuhan kebutuhan informasi keuangan secara umum yang lebih berkualitas bagi para pengguna laporan keuangan dalam rangka menilai akuntabilitas dan membuat keputusan ekonomi, sosial maupun politik. Bagi para pengawas keuangan daerah, laporan keuangan yang berbasis standar akuntansi memberikan tantangan baru dalam peningkatan aspek pengawasan terhadap kualitas laporan keuangan pemerintah. Tantangan tersebut adalah kemampuan pihak pengawas dalam mengungkap kewajaran penyajian laporan keuangan melalui opini yang diberikannya. Kemampuan ini tentunya diharapkan memperbaiki pengelolaan keuangan daerah.

Penerapan akuntansi yang baik oleh instansi pemerintah akan menghasilkan laporan keuangan instansi pemerintah yang baik. Pengawasan yang optimal terhadap kualitas laporan keuangan instansi pemerintah akan menjamin bahwa laporan keuangan tersebut disajikan secara benar dan wajar sesuai Standar Akuntansi Keuangan Pemerintahan sehingga informasi yang terdapat dalam laporan keuangan tersebut dapat dimanfaatkan sebagai bahan pengambil keputusan.

Dinas Pekerjaan Umum Bina Marga dan Tata Ruang Provinsi Sumatera Selatan merupakan salah satu Dinas yang harus melaksanakan penerapan sistem akuntansi pemerintah pada pengelolaan keuangan daerah secara baik dan benar pada setiap periode pelaporan. Sejalan dengan akan diterapkannya SAP berbasis Akrual Pada Pemerintah Pusat maupun Pemerintah Daerah, dan dengan direvisinya PP No. 24 Tahun 2005 menjadi PP No. 71 Tahun 2010 membawa beberapa perubahan dalam standar dan mekanisme penyajian laporan keuangan. Di dalam perubahan tersebut, terdapat beberapa kendala dalam pelaksanaan penerapan Standar Akuntansi Pemerintah PP No. 71 Tahun 2010 seperti kurangnya sosialisasi dan bimbingan teknik sehingga dalam pembukuannya sangat sedikit yang mengetahui sistem akuntansi pemerintahan yang telah berubah. Selain itu, kurangnya Sumber Daya Manusia (SDM) yang berkompeten yaitu aparatur 
pemerintah daerah yang memiliki kemampuan berupa pengetahuan, keterampilan, sikap dan prilaku terhadap pengelolaan keuangan khususnya dibidang akuntansi serta sistem informasi/ perangkat yang digunakan dan komitmen organisasi menjadi kendala dalam menerapkan Standar Akuntansi Pemerintahan Berdasarkan PP No. 71 Tahun 2010 dalam mewujudkan kualitas dan keandalan laporan keuangan.

Dinas Pekerjaan Umum Bina Marga dan Tata Ruang Provinsi Sumatera Selatan sebagai salah satu entitas pelaporan dalam menyajikan laporan keuangan pada Tahun Anggaran 2014 masih menggunakan PP No. 24 Tahun 2005 berbasis Kas Menuju Akrual. Laporan keuangan yang disajikan pada tahun 2014 meliputi Laporan realisasi anggaran, neraca, laporan arus kas, dan catatan atas laporan keuangan. Kemudian Pemerintah membuat revisi menjadi PP No. 71 Tahun 2010 terhadap laporan keuangan berbasis akrual dengan menyiapkan SDM yang berkompeten, SIMDA yang merupakan perangkat pendukung dan Komitmen Organisasi. Laporan keuangan yang disajikan pada tahun 2015 meliputi Laporan realisasi anggaran, laporan perubahan saldo anggaran lebih (laporan perubahan $\mathrm{SAL}$ ), neraca, laporan arus kas, laporan perubahan ekuitas, laporan operasional dan catatan atas laporan keuangan. Dinas Pekerjaan Umum Bina Marga dan Tata Ruang Provinsi Sumatera Selatan merupakan Badan Layanan Umum (BLU)sebagai entitas akuntansi yang menjadi bagian dari sistem akuntansi dan pelaporan keuangan pemerintah daerah tentunya memegang peranan penting dalam menyediakan data dan informasi yang lengkap dan benar demi mencapai kualitas laporan keuangan. Research gap dalam penulisan ini melihat penelitian Fatmawati (2016) yang menunjukkan bahwa kantor Pemerintah Provinsi DKI Jakarta telah menerapkan SAP berbasis Akrual.

\section{B. KAJIAN TEORI}

\section{Standar Akuntansi Pemerintahan (SAP)}

Pemerintah telah menetapkan Undang-Undang Nomor 17 Tahun 2003 tentang keuangan negara yang mengatur tentang pertanggungjawaban pelaksanaan Anggaran Pendapatan dan Belanja Negara (APBN) berupa laporan keuangan yang telah diperiksa Badan Pemeriksa Keuangan (BPK), namun pemerintah pusat maupun daerah belum bisa menyusun laporan keuangan karna hal ini disebabkan belum tersedianya standar yang mengatur tentang bentuk dan isi laporan keuangan pada saat itu.

Menurut Komite Standar Akuntansi Pemerintahan mengatakan bahwa SAP adalah prinsip-prinsip akuntansi yang diterapkan dalam menyusun dan menyajikan laporan keuangan pemerintah. Dengan demikian SAP merupakan persyaratan yang mempunyai kekuatan hukum dalam upaya meningkatkan kualitas laporan keuangan di Indonesia (Peraturan Pemerintah RI No 71 Tahun 2010).

Komite SAP bertugas menyiapkan penyusunan konsep Rancangan Peraturan Pemerintah tentang SAP sebagai prinsip-prinsip akuntansi yang wajib diterapkan dalam menyusun dan menyajikan laporan keuangan pemerintah pusat dan pemerintah daerah. Komite Standar Akuntansi Pemerintah (KSAP) bertujuan mengembangkan program-program pengembangan akuntabilitas dan manajemen keuangan pemerintahan,termasuk mengembangkan SAP.

\section{Tujuan Akuntansi Pemerintahan}

Menurut Renyowijoyo (2010:27) menyatakan adapun tujuan dari Akuntansi Pemerintahan adalah sebagai berikut : Ada 3 tujuan pokok Akuntansi Pemerintahan, 
yaitu :

a. Pertanggungjawaban (Accountability and stewardship) : Informasi keuangan yang berguna bagi penanggung jawab pemerintahan.

b. Manajerial (Managerial) : Informasi keuangan yang berguna untuk perumusan kebijaksanaan, pengambilan keputusan dan penilaiaan kinerja pemerintah.

c. Pengawasan (Control) : Akuntansi pemerintahan memungkinkan terselenggaranya pemeriksaan oleh aparat fungsional secara efektif dan efisien. Sedangkan secara umum, tujuan akuntansi pemerintahan adalah memberikan jasa dan pelayanan kepada masyarakat. adalah :

Sedangkan tujuan Akuntansi Pemerintah menurut Abdul Halim (2010:28)

a. Pertanggungjawaban (accountability dan stewardship)

Tujuan pertanggungjawaban memiliki arti memberikan informasi keuangan yang lengkap cermat, dalam bentuk dan waktu yang tepat, yang berguna bagi pihak yang bertanggungjawab yang berkaitan dengan operasi unit-unit pemerintah. Lebih lanjut, tujuan pertanggungjawaban ini mengharuskan tiap orang atau badan yang mengelola keuangan negara harus memberikan pertanggungjawaban dan perhitungan.

b. Manajerial

Tujuan manajerial berarti bahwa akuntansi pemerintah harus menyediakan informasi keuangan yang diperlukan untuk perencanaan, penganggaran, pelaksanaan, pemantauan, pengendalian anggaran, perumusan kebijaksanaan dan pengambilan keputusan, serta penilaian kinerja pemerintah.

c. Pengawasan

Tujuan pengawasan memiliki arti bahwa akuntansi pemerintah harus memungkinkan terselenggaranya pemeriksaan aparat pengawasan fungsional secara efektif dan efisien.

Dari definisi yang dikemukakan diatas maka dapat penulis simpulkan bahwa tujuan akuntansi pemerintahan terdiri dari akuntabilitas pemerintah yaitu berkaitan dengan informasi yang lengkap dan cermat, manajerial yaitu yang berkaitan dengan perencanaan, penganggaran, perumusan kebijaksanaan, pengambilan keputusan dan penilaiaan kinerja dan pengawasan terhadap laporan keuangan secara efektif dan efisien. Dari keterangan tersebut di atas, diharapkan dengan adanya akuntansi pemerintah, mampu membangun hubungan kepercayaan yang baik antara pemerintah baik pusat maupun daerah dengan masyarakat melalui informasi yang disajikan dalam laporan keuangan dengan tujuan untuk mensejahterakan masyarakat. Penerapan SAP diyakini akan berdampak pada peningkatan kualitas pelaporan keuangan di pemerintahan pusat dan daerah.

\section{Kerangka Konseptual Standar Akuntansi Pemerintahan (SAP)}

SAP diterapkan dilingkungan pemerintahan, yaitu pemerintah pusat, pemerintah daerah, dan satuan organisasi dilingkungan pemerintah pusat/daerah, jika menurut peraturan perundang-undangan satuan organisasi dimaksud wajib menyajikan laporan keuangan.

Keterbatasan dari penerapan SAP akan dinyatakan secara eksplisit pada setiap standar yang diterbitkan. Proses penyiapan SAP merupakan mekanisme prosedural yang meliputi tahap-tahap kegiatan yang dilakukan dalam setiap penyusunan 
Pernyataan Standar Akuntansi Pemerintahan (PSAP) oleh komite.

Menurut Bastian (2010:77) mengatakan bahwa kandungan yang berada pada akuntansi pemerintahan adalah mencakup akuntansi manajemen, sistem akuntansi keuangan, perencanaan keuangan dan pembangunan, sistem pengawasan dan pemeriksaan, serta berbagai implikasi finansial atas kebijakan-kebijakan yang dilakukan pemerintah.

SAP menurut PP No. 71 Tahun 2010 terdiri dari Kerangka Konseptual dan 12 Pernyataan Standar Akuntansi Pemerintahan (PSAP), yaitu :

$\checkmark$ PSAP 01 tentang Penyajian Laporan Keuangan

$\checkmark$ PSAP 02 tentan Laporan Realisasi Anggaran Berbasis Kas

$\checkmark$ PSAP 03 tentang Laporan Arus Kas

$\checkmark$ PSAP 04 tentang Catatan Atas Laporan Keuangan

$\checkmark$ PSAP 05 tentang Akuntansi Persediaan

$\checkmark$ PSAP 06 tentang Akuntansi Investasi

$\checkmark$ PSAP 07 tentang Akuntansu Aset Tetap

$\checkmark$ PSAP 08 tentang Akuntansi Konstruksi Dalam Pengerjaan

$\checkmark$ PSAP 09 tentang Akuntansi Kewajiban

$\checkmark$ PSAP 10 tentang Koreksi Kesalahan, Perubahan Kebijakan Akuntansi, Perubahan Estimasi Akuntansi dan Operasi YangTidak dilanjutkan.

$\checkmark$ PSAP 11 tentang Laporan Keuangan Konsolidasian

$\checkmark$ PSAP 12 tentang Laporan Operasional

Dengan adanya SAP maka laporan keuangan pemerintah pusat/daerah akan lebih berkualitas (dapat dipahami, relevan, andal dan dapat diperbandingkan) dan laporan tersebut akan diaudit terlebih dahulu oleh BPK untuk diberikan opini dalam rangka meningkatkan kredibilitas laporan, sebelum disampaikan kepada para stakeholder antara lain: pemerintah (eksekutif), DPR/DPRD (legislatif), investor, kreditor, dan masyarakat pada umumnya dalam rangka transparansi dan akuntabilitas keuangan negara.

\section{Pengguna dan Kebutuhan Informasi Para Pengguna}

Menurut Peraturan Pemerintah (PP) No. 71 Tahun 2010, Kelompok utama pengguna laporan keuangan pemerintah, namun tidak terbatas pada :

- Masyarakat

- Para wakil rakyat, lembaga pengawas, dan lembaga peeriksa

- Pihak yang member atau berperan dalam proses donasi, investasi, dan pinjaman

- Pemerintah

Sedangkan menurut kerangka konseptual akuntansi pemerintahan, terdapat beberapa kelompok utama pengguna laporan keuangan pemerintah daerah yaitu :

a. Masyarakat

Informasi tentang pertanggungjawaban pelaksanaan APBD dibutuhkan oleh masyarakat dalam menilai transparasi dan akuntabilitas pengelolaan keuangan daerah yang pendanaannya sebagian besar dari pembayaran pajak dan retribusi yang dilakukan oleh rakyat.

b. Para Wakil Rakyat (DPRD)

Lembaga legislatif berkepentingan terhadap informasi yang dihasilkan oleh akuntansi keuangan daerah dalam rangka mengawasi dan menjaga 
keseimbangan terhadap kemungkinan penyalahgunan kekuasaan.

c. Lembaga Pemeriksa

Lembaga Pemeriksa seperti Badan Pemeriksa Keuangan (BPK) berkepentingan terhadap informasi akuntansi keuangan daerah untuk memeriksa dan memberikan opini apakah pemda dalam pengelolaan keuangannya sudah sesuai dengan peraturan perundang-undangan.

d. Analis dan Peneliti

Informasi yang dihasilkan dari pelaporan keuangan pemda biasanya diwujudkan dalam database Sistem Informasi Keuangan Daerah (SIKD) sangat diperlukan oleh analis maupun peneliti yang digunakan untuk membuat analisis dan riset tentang berbagai hal yang terkait dengan kemampuan ekonomi suatu pemda.

e. Pihak yang memberi atau berperan dalam proses donasi, investasi dan pinjaman

Informasi keuangan daerah dipergunakan oleh pihak yang memberikan donasi untuk melihat apakah donasi yang diberikannya sudah sesuai dengan tujuan peruntukkannya. Investor berkepentingan menggunakan informasi keuangan daerah dalam rangka pengambilan keputusan ekonomi terkait dengan investasi yang telah atau akan dilakukannya. Pihak yang akan memberikan pinjaman berkepentinagan untuk menilai apakah entitas pemda mempunyai kapabilitas ekonomi untuk mengembalikan pinjaman yang diberikan.

f. Pemerintah Pusat

Pemerintah pusat memerlukan informasi pelaporan keuangan pemda untuk mengevaluasi pertanggungjawaban Kepala Daerah karena adanya desentralisasi dalam pengelolaan keuangan negara yang diserahkan kepada Gubernur / Bupati/ Walikota selaku pengelola keuangan daerah

g. Pemerintah Daerah Lainnya

Sesuai dengan karakteristik utama struktur pemerintahan seperti yang telah diuraikan diatas khususnya adanya transfer pendapatan antar pemerintah, maka pemda lain memerlukan informasi pelaporan keuangan pemda lainnya.

Laporan keuangan pemerintah tidak dirancang untuk memenuhi tujuan spesifikasi dari masing-masing kelompok pengguna karena informasi yang disajikan dalam laporan keuangan bertujuan umum guna memenuhi kebutuhan informasi dari semua kelompok pengguna. Namun pajak sumber utama pendapatan pemerintah, maka kebutuhan informasi para pembayar pajak perlu mendapatkan perhatian.

\section{Peranan dan Tujuan Pelaporan Keuangan}

Laporan keuangan disusun untuk menyediakan informasi yang relevan mengenai posisi keuangan dan seluruh transaksi yang dilakukan suatu entitas pelaporan selama satu periode pelaporan. Laporan keuangan terutama digunakan untuk membandingkan realisasi pendapatan, belanja, transfer, dan pembiayaan dengan anggaran yang telah ditetapkan, menilai kondisi keuangan, mengevaluasi efektivitas dan efisiensi suatu entitas pelaporan, dan membantu menentukan ketaatannya terhadap peraturan perundang-undangan.

Menurut PP No. 71 Tahun 2010 setiap entitas pelaporan mempunyai kewajiban untuk melaporkan upaya-upaya yang telah dilakukan serta hasil yang dicapai dalam pelaksanaan kegiatan secara sistematis dan terstruktur pada periode pelaporan untuk kepentingan : 
a. Akuntabilitas

Mempertanggungjawabkan pengelolaan sumber daya serta pelaksanaan kebijakan yang dipercayakan kepada entitas pelaporan dalam mencapai tujuan yang telah ditetapkan secara periodik.

b. Manajemen

Membantu para pengguna untuk mengevaluasi pelaksanaan kegiatan suatu entitas pelaporan dalam periode pelaporan sehingga memudahkan fungsi perencanaan, pengelolaan dan pengendalian atas seluruh asset, kewajiban, dan ekuitas dana pemerintah untuk kepentingan masyarakat.

c. Transparasi

Memberikan informasi keuangan yang terbuka dan jujur kepada masyarakat berdasarkan pertimbangan bahwa masyarakat memiliki hak untuk mengetahui secara terbuka dan menyeluruh atas pertanggungjawaban pemerintah dalam pengelolaan sumber daya yang dipercayakan kepadanya dan ketaatanya pada peraturan perundang-undangan.

d. Keseimbangan Antargenerasi (intergeneration equity)

Membantu para pengguna dalam mengetahui kecukupan penerimaan pemerintah pada periode pelaporan untuk membiayai seluruh pengeluaran yang dialokasikan dan apakah generasi yang akan datang diasumsikan akan ikut menanggung beban pengeluaran tersebut.

e. Evaluasi Kinerja

Mengevaluasi kinerja entitas pelaporan, terutama dalam penggunaan sumber daya ekonomi yang dikelola pemerintah untuk mencapai kinerja yang direncanakan.

Adapun tujuan pelaporan keuangan pemerintah adalah untuk menyajikan informasi yang berguna untuk pengambilan keputusan. Menurut Mardiasmo (2018:203) memaparkan bahwa secara garis besar, Tujuan umum penyajian laporan keuangan oleh pemerintah daerah adalah sebagai berikut :

1. Untuk memberikan informasi yang digunakan dalam pembuatan keputusan ekonomi, social dan politik sebagai bukti pertanggungjawaban (accountability) dan pengelolaan (stewardship).

2. Untuk memberikan informasi yang digunakan untuk mengevaluasi kinerja manajerial dan organisasi.

Mardiasmo (2018: 205) secara khusus, tujuan penyajian laporan keuangan oleh pemerintah daerah adalah sebagai berikut :

a. Memberikan informasi keuangan untuk menentukan dan memprediksi aliran kas, saldo neraca, dan kebutuhan sumber daya financial jangka pendek unit pemerintah.

b. Memberikan informasi keuangan untuk menentukan dan memprediksi kondisi ekonomi suatu unit pemerintahan dan perubahan-perubahan yang terjadi didalamnya.

c. Memberikan informasi keuangan untuk memonitor kinerja, kesesuaianya dengan peraturan perundang-undangan, kontrak yang telah disepakati dan ketentuan lain yang diisyaratkan.

d. Memberikan informasi bentuk perencanaan dan penganggaran, serta untuk memprediksi pengaruh pemilikan dan pembelanjaan sumber daya ekonomi terhadap pencapaian tujuan operasional. 
e. Memberikan informasi untuk mengevaluasi kinerja dan organisasional.

Berdasarkan PP No. 71 Tahun 2010 tentang Standar Akuntansi Pemerintah (SAP) menyatakan bahwa pelaporan keuangan pemerintah seharusnya menyajikan informasi bagi para pengguna untuk menilai akuntabilitas dan membuat keputusan baik keputusan ekonomi, sosial, politik dengan cara :

1. Menyediakan informasi tentang sumber, alokasi, dan penggunaan sumber daya keuangan.

2. Menyediakan informasi mengenai kecukupan penerimaan periode berjalan untuk membiayai seluruh pengeluaran

3. Menyediakan informasi mengenai jumlah sumber daya ekonomi yang digunakan dalam kegiatan entitas pelaporan serta hasil-hasil yang telah dicapai.

4. Menyediakan informasi mengenai bagaimana entitas pelaporan mendanai seluruh kegiatannya dan mencukupi kebutuhan kasnya.

5. Menyediakan informasi mengenai posisi keuangan dan kondisi entitas pelaporan berkaitan dengan sumber-sumber penerimaannya, baik jangka pendek maupun jangka panjang termasuk yang berasal dari pungutan pajak dan pinjaman.

6. Menyediakan informasi mengenai perubahan posisi keuangan entitas pelaporan, apakah mengalami kenaikan atau penurunan, sebagai akibat kegiatan yang dilakukan selama periode pelaporan.

Untuk memenuhi tujuan-tujuan tersebut, laporan keuangan menyediakan informasi mengenai pendapatan, belanja, transfer, dana cadangan, pembiayaan, asset, kewajiban, ekuitas dana dan arus kas suatu entitas pelaporan.

\section{Basis Akuntansi Pemerintah}

Basis akuntansi merupakan prinsip-prinsip akuntansi yang menerapkan kapan pengaruh atas transaksi atau kejadian harus diakui untuk tujuan pelaporan keuangan. Menurut KSAP PP No. 71 Tahun 2010, bahwa basis akuntansi ada 2 (dua), yaitu:

a) Basis Kas (Cash Basis of Accounting)

Basis Kas merupakan salah satu konsep yang sangat penting dalam akuntansi, dimana pencatatan basis kas adalah teknik pencatatan ketika transaksi terjadi dimana uang benar-benar diterima atau dikeluarkan. Dengan kata lain Akuntansi Basis Kas adalah basis akuntansi yang mengakui pengaruh transaksi dan peristiwa lainnya pada saat kas atau setara kas diterima atau dibayar yang digunakan untuk pengakuan pendapatan belanja dan pembiayaan. Akuntansi berbasis kas ini tentu memiliki kelebihan dan keterbatasan. Kelebihan-kelebihan akuntansi berbasis kas adalah laporan keuangan berbasis kas memperlihatkan sumber dana, alokasi, dan penggunaan sumber-sumber kas, mudah untuk dimengerti dan dijelaskan, pembuat laporan keuangan tidak membutuhkan pengetahuan yang mendetail tentang akuntansi dan tidak memerlukan pertimbangan ketika menentukan jumlah arus kas dalam suatu periode. Sementara itu keterbatasan akuntansi berbasis kas adalah hanya memfokuskan pada arus kas dalam periode pelaporan berjalan, dan mengabaikan arus sumber daya lain yang mungkin berpengaruh pada kemampuan pemerintah untuk menyediakan barang-barang 
danjasa-jasa saat sekarang dan saat mendatang, laporan posisi keuangan (neraca) tidak dapat disajikan karena tidak terdapat pencatatan secara double entry, tidak dapat menyediakan informasi mengenai biaya pelayanan (cost of service) sebagai alat untuk penetapan harga (pricing), kebijakan kontrak publik, untuk kontrol dan evaluasi kinerja.

\section{b. Basis Akrual}

Teknik Basis Akrual memiliki fitur pencatatan dimana transaksi sudah dapat dicatat karena transaksi tersebut memiliki implikasi uang masuk atau keluar di masa depan. Transaksi dicatat pada saat terjadinya transaksi walaupun uang belum benar-benar diterima atau dikeluarkan. Dengan kata lain basis akrual digunakan untuk pengukuran aset, kewajiban dan ekuitas dana. Jadi basis akrual adalah basis akuntansi yang mengakui pengaruh transaksi dan peristiwa itu terjadi tanpa memperhatikan saat kas atau setara kas diterima atau dibayar.

Basis akrual adalah : Suatu basis akuntansi dimana transaksi ekonomi atau peristiwa akuntansi diakui, dicatat, dan disajikan dalam laporan keuangan pada saat terjadinya transaksi tersebut, tanpa memperhatikan waktu kas diterima atau dibayarkan.

Dalam akuntansi berbasis akrual, waktu pencatatan (recording) sesuai dengan saat terjadinya arus sumber daya, sehingga dapat menyediakan informasi yang paling komprehensif karena seluruh arus sumber daya dicatat. Basis akrual menyediakan informasi yang paling komprehensif karena seluruh arus sumber daya dicatat,termasuk transaksi internal dan arus ekonomi lainnya. Secara sederhana, dikatakan bahwa penerapan akuntansi berbasis akrual ditujukan untuk mengatasi ketidakcukupan basis kas untuk memberikan data yang lebih akurat. Heather Thompson dalam Bambang Widjajarso (2010:97) menyampaikan beberapa tujuan penggunaan basis akrual yakni sebagai berikut:

1. Untuk meningkatkan efisiensi dan efektivitas sistem keuangan dalam sektor publik.

2. Untuk meningkatkan pengendalian fiskal, manajemen aset dan budaya sector publik.

3. Untuk meningkatkan akuntabilitas dalam program penyediaan barang dan jasa oleh pemerintah.

4. Menyediakan informasi yang lebih lengkap bagi pemerintah untuk mengambil keputusan.

5. Untuk mereformasi sistem anggaran belanja.

6. Untuk mencapai tramsparasi yang lebih luas atas biaya pelayanan yang dilakukan oleh pemerintah.

Dengan demikian,tujuan penerapan basis akuntansi akrual pada dasarnya untuk memperoleh informasi yang tepat atas jasa yang diberikan pemerintah dengan lebih transparan. Tujuan penerapan basis akrual lainnya adalah untuk meningkatkan kualitas pengambilan keputusan pemerintah.

Manfaat-manfaat penerapan basis akrual menurut $\mathrm{H}$ Thompson dalam Bambang Widjajarso (2010:101),akan mencakup hal-hal seperti:

a. Menyediakan gambaran yang utuh atas posisi keuangan pemerintah.

b. Menunjukkan bagaimana aktifitas pemerintah dibiayai dan bagaimana pemerintah dapat memenuhi kebutuhan kasnya.

c. Menyediakan informasi yang berguna tentang tingkat yang sebenarnya 
kewajiban pemerintah.

d. Meningkatkan daya pengelolaan aset dan kewajiban pemerintah.

e. Basis akrual sangat familiar pada lebih banyak orang dan lebih komprehensif dalam penyajian informasinya.

\section{Komponen Laporan Keuangan}

Peraturan Pemerintah No. 71 tahun 2010 tentang standar akuntansi pemerintahan merupakan pedoman dalam menyusun laporan keuangan yang digunakan sampai saat ini. Basis akuntansi yang digunakan dalam SAP ini adalah basis kas menuju akrual (cash toward accrual), dimana penggunaan basis kas untuk pengakuan pendapatan,belanja,transfer, dan pembiayaan serta basis akrual untuk pengakuan aset, kewajiban, dan ekuitas dana.

\section{Peraturan Pemerintah (PP) No. 71 Tahun 2010 Berbasis Akrual}

Basis akuntansi berbasis Kas Menuju Akrual merupakan suatu pendekatan unik yang dikembangkan oleh Indonesia untuk dapat menyajikan empat laporan keuangan pokok yang diamanatkan Undang-Undang (UU) dan disesuaikan dengan kondisi (peraturan, sistem, sarana dan prasarana, serta Sumber Daya Manusia) di Indonesia yang sampai dengan tahun 2004 masih menggunakan pembukuan tradisional (single entry) berbasis kas, belum menggunakan akuntansi modern (double entry) sehingga sangat sulit atau bahkan tidak mungkin bila langsung menerapkan akuntansi modern berbasis akrual. Basis kas menuju akrual relatif tidak dikenal di negara-negara lain, yang merupakan pendekatan transisi dari kas menuju akrual yang berhasil. Basis kas menuju akrual ini pada dasarnya merupakan suatu pendekatan Basis Akuntansi Modified Accrual, sistem akuntansi dan aplikasi komputer yang digunakan dan dikembangkan sendiri.

Pada Tahun 2005, pemerintah menetapkan Peraturan Pemerintah (PP) Nomor 24 Tahun 2005 tentang Standar Akuntansi Pemerintahan (SAP) yang mengatur mengenai pengakuan pendapatan dan belanja menggunakan basis kas, sedangkan untuk aset, kewajiban, dan ekuitas menggunakan basis akrual. Untuk menghasilkan Laporan Keuangan Pemerintah Pusat (LKPP) yang sesuai dengan SAP, Pemerintah juga mengembangkan Sistem Akuntansi Pemerintah Pusat berbasis kas menuju akrual. Untuk penyeragaman mekanisme penyajian informasi pendapatan dan belanja secara akrual, diterbitkan Peraturan Dirjen Perbendaharaan (Perdirjen) Nomor 62 Tahun 2009 tentang Tata Cara Penyajian Informasi Pendapatan dan Belanja secara Akrual pada Laporan Keuangan.

Penyusunan laporan keuangan dengan akuntansi berbasis Kas Menuju Akrual, pemerintah pusat saat ini sudah dapat menyediakan laporan keuangan sebagaimana diamanatkan UU, Kementerian/Lembaga juga telah dapat mengimplementasikan relatif cukup baik dan telah cukup baik menyediakan informasi akrual walaupun secara periodik dan dengan usaha-usaha tambahan yang tidak berdasarkan sistem.

Namun ada beberapa hal yang belum bisa dipenuhi dengan akuntansi Kas Menuju Akrual. Hal pertama adalah laporan keuangan berbasis kas menuju akrual belum memperlihatkan kinerja pemerintah secara keseluruhan, saat ini hanya fokus pada sumber daya keuangan berupa kas (financial assets). Laporan keuangan juga tidak menggambarkan beban keuangan yang sesungguhnya, karena beban yang diakrualkan (misalnya beban penyusutan, beban penyisihan piutang tak tertagih, dan beban yang terutang lainnya) tidak diinformasikan dalam Laporan Realisasi Anggaran maupun laporan lainnya, hanya memberikan gambaran parsial bukan 
menyeluruh tentang keuangan negara sesuai maksud UU 17 Tahun 2003. Selain itu laporan keuangan berbasis Kas Menuju Akrual juga kurang memberikan rekam jejak atas perubahan nilai ekuitas pemerintah, karena setiap transaksi terkait aset dan kewajiban akan langsung membebani ekuitas. Dengan demikian informasi akrual hanya dapat disajikan secara periodik yaitu pada saat pelaporan (semester dan tahunan). Bila sewaktu-waktu dibutuhkan informasi hak dan kewajiban maka diperlukan usaha-usaha tambahan yang tidak berdasarkan sistem (by system).

Sedangkan Kelebihan Basis akrual adalah dapat menyediakan laporan keuangan sebagaimana diamanatkan UU, Kementerian/Lembaga telah dapat mengimplementasikan relatif cukup baik dan telah menyediakan informasi akrual walaupun secara periodik dan dengan usaha-usaha tambahan yang tidak berdasarkan sistem.

Kekurangan yang terjadi dalam penerapan basis akrual adalah Biaya yang belum dibayarkan secara kas, akan dicatat efektif sebagai biaya sehingga dapat mengurangi pendapatan dan tidak ada perkiraan yang tepat kapan kas yang belum dibayarkan oleh pihak lain dapat diterima. Adapun kelebihan dari basis akrual adalah Beban diakui saat terjadi transaksi sehingga informasi yang diberikan lebih andal dan terpercaya dan laporan keuangan dapat dijadikan sebagai pedoman dalam menentukan kebijakan dimasa datang dengan lebih tepat.

\section{Sistem Informasi (Perangkat yang digunakan)}

Menurut Agus Mulyanto (2009 : 29) mendefinisikan sistem informasi sebagai suatu komponen yang terdiri dari manusia, teknologi informasi, dan prosedur kerja yang memproses, menyimpan, menganalisis, dan menyebarkan informasi untuk mencapai suatu tujuan. Sedangkan Menurut Yakub (2012:20), bahwa Sistem informasi merupakan sebuah susunan yang terdiri dari beberapa komponen atau elemen.

Dari penjelasan beberapa ahli diatas maka dapat penulis simpulkan bahwa sistem informasi merupakan suatu komponen yang terdiri dari manusia, teknologi dan prosedur kerja untuk mencapai suatu tujuan.

Menurut Mustakini (2009:42), bahwa sistem informasi mempunyai enam buah komponen, yaitu:

a. Komponen input atau komponen masukan,

b. Komponen model,

c. Komponen output atau komponen keluaran

d. Komponen teknologi,

e. Komponen basis data,

f. Komponen kontrol atau komponen pengendalian.

Keenam komponen ini harus ada dan membentuk satu kesatuan. Jika satu atau lebih komponen tersebut tidak ada, maka sistem informasi tidak akan dapat melakukan fungsinya, yaitu pengolahan data dan tidak dapat mencapai tujuannya, yaitu menghasilkan informasi yang relevan, tepat waktu dan akurat.

\section{METODE PENELITIAN}

Dalam penelitian ini penulis menggunakan metode deskriptif kualitatif. Moleong (2010:11) metode deskriptif kualitatif artinya "Data yang dikumpulkan bukan berupa data angka,melainkan data yang berasal dari naskah wawancara, catatan lapangan, dokumen pribadi, catatan atau memo peneliti dan dokumen resmi lain yang 
mendukung".

\section{1) Variabel Penelitian}

Menurut Sugiyono (2017:38) menyebutkan bahwa variabel penelitian adalah "Segala sesuatu yang berbentuk apa saja yang ditetapkan oleh peneliti untuk mempelajari sehingga diperoleh informasi tentang hasil tersebut,kemudian ditarik kesimpulan".

Dalam penelitian ini, variabel yang digunakan adalah Standar Akuntansi Pemerintahan dengan definisi operasional prinsip-prinsip Akuntansi yang diterapkan dalam menyusun dan menyajikan laporan keuangan pemerintahan, indikatornya dapat diukur dari sumber daya manusia, alat/perangkat yang memadai dan komitmen organisasi dalam menerapkan peraturan yang telah ditetapkan oleh pemerintah. Secara ringkas, variabel dan definisi operasional dapat dituangkan sebagai berikut :

\section{Tabel Variabel Dan Definisi Istilah}

\begin{tabular}{|c|c|c|c|}
\hline No & Variabel & Definisi Operasional & Indikator \\
\hline 1. & $\begin{array}{l}\text { Standar } \\
\text { Akuntansi } \\
\text { Pemerintah }\end{array}$ & $\begin{array}{l}\text { prinsip-prinsip Akuntansi } \\
\text { yang diterapkan dalam } \\
\text { menyusun dan } \\
\text { menyajikan laporan } \\
\text { keuangan pemerintahan. }\end{array}$ & $\begin{array}{ll}\text { - } & \text { Laporan Realisasi Anggaran } \\
& \text { (LRA) } \\
\text { - } & \text { Laporan Perubahan Saldo } \\
& \text { Anggaran Lebih (SAL) } \\
\text { - } & \text { Neraca } \\
\text { - } & \text { Laporan Operasional (LO) } \\
\text { - } & \text { Laporan Arus Kas (LAK) } \\
\text { - } & \text { Laporan Perubahan Ekuitas } \\
& \text { (LPE) } \\
\text { - Catatan atas Laporan } \\
\text { Keuangan }\end{array}$ \\
\hline
\end{tabular}

\section{2) Populasi}

Menurut Sugiyono (2012:61), yaitu sebagai berikut: "Populasi adalah wilayah generalisasi yang terdiri atas: obyek/subyek yang mempunyai kualitas dan karakteristik tertentu yang ditetapkan oleh peneliti untuk dipelajari dan kemudian ditarik kesimpulannya". Populasi dalam penelitian ini adalah Laporan Keuangan di Dinas Pekerjaan Umum Bina Marga dan Tata Ruang Provinsi Sumatera Selatan

\section{3) Sampel}

Menurut Sugiyono (2012:62) sampel adalah "Bagian dari jumlah dan karakteristik yang dimiliki oleh populasi tersebut". Sampel yang digunakan dalam penelitian ini adalah Laporan Keuangan di Dinas Pekerjaan Umum Bina Marga dan Tata Ruang Provinsi Sumatera Selatan Tahun Anggaran 2015 s/d 2018 .

\section{4) Teknik Pengumpulan Data}

Menurut Semiawan (2010:103) teknik pengumpulan data adalah sebagai berikut :
a) Wawancara
Wawancara (interview) adalah suatu kejadian atau suatu proses interaksi antara pewawancara (interviewer) dan sumber informasi atau orang yang di wawancarai (interviewee) melalui komunikasi langsung
b) Metode Observasi (Pengamatan) 
Observasi berarti mengumpulkan data langsung dari lapangan.

c) Metode Dokumentasi

Metode dokumentasi adalah metode pengumpulan data yang digunakan untuk menelusuri data historis. Dokumen tentang orang atau sekelompok orang, peristiwa atau kejadian dalam situasi sosial yang sangat berguna dalam penelitian kualitatif

d) Angket ( Questioner)

Angket adalah responden mengisi kuesioner yang disusun oleh peneliti.

Dalam penelitian ini penulis menggunakan teknik pengumpulan data observasi, wawancara dan dokumentasi.

\section{5) Teknik Analisis Data}

Menurut Silalahi (2010:304) metode analisis data ini terbagi menjadi dua yaitu sebagai berikut :

$>$ Metode analisis kualitatif berupa catatan-catatan yang biasanya cenderung banyak sehingga memerlukan waktu yang cukup lama untuk menganalisisnya secara seksama. Dalam analisis data kualitatif adalah penyajian data dimana berarti sebagai sekumpulan informasi yang tersusun yang memberi kemungkinan akan adanya penarikan kesimpulan dan pengambilan tindakan tertentu.

$>$ Metode analisis kuantitatif menggunakan data statistik dan dapat dilakukan dengan cepat. Metode kuantitatif ini menggunakan statistik sebagai alat analisis datanya.

Dalam Penelitian ini penulis menggunakan teknik analisis data yaitu analisis deskriptif kualitatif dengan menggunakan pendekatan deskriptif. Metode ini memaparkan sesuatu dengan cara mendeskripsikan, mencatat, menganalisis dan menginterpretasikan kondisi yang saat ini terjadi. Metode analisis deskriptif sesuai dengan hakikatnya adalah data yang telah terkumpul kemudian diseleksi, dikelompokkan, dilakukan pengkajian, intepretasi dan disimpulkan. Selanjutnya hasil kesimpulan itu dideskripsikan. Adapun langkah-langkah yang peneliti lakukan adalah sebagai berikut :

a) Melakukan wawancara dengan informan mengenai laporan keuangan yang diperlukan dalam penelitian ini.

b) Membandingkan data wawancara antar informan yang satu dengan yang lainnya.

c) Membandingkan data wawancara dengan dokumentasi yang telah dikumpulkan.

d) Menarik kesimpulan.

\section{HASIL PENELITIAN}

1) Penerapan SAP di Dinas PU Bina Marga dan Tata Ruang Provinsi Sumatera Selatan

Peraturan Pemerintah Nomor 71 tahun 2010 tentang Standar Akuntansi Pemerintahan, berbuah keputusan penghapusan standar akuntansi pemerintah nomor 24 tahun 2005 berbasis kas menuju akrual. Sejalan dengan amanat Undangundang No. 17 tahun 2003 tentang Keuangan Negara dan Undang-Undang No. 1 Tahun 2004 tentang Pembendaharaan Negara, maka Pemerintah Pusat akan menerapkan akuntansi berbasis akrual. Pasal 12 dan 13 UU No. 1 tahun 2004 
tentang Pembendaharaan Negara menyatakan bahwa pendapatan dan belanja dalam APBN dicatat menggunakan basis akrual. Hal ini didasarkan atas pertimbangan bahwa basis akrual dapat memberikan informasi keuangan yang lebih lengkap daripada basis lainnya, terutama untuk informasi piutang dan utang pemerintah. Selain itu, laporan keuangan berbasis akrual juga menyediakan informasi mengenai kegiatan operasional pemerintah, evaluasi efisiensi dan efektivitas serta ketaatan terhadap peraturan.

Penerapan standar akuntansi pemerintah (SAP) berbasis akrual penuh selambat-lambatnya dimulai tahun 2015. Sebagaimana disebutkan dalam peraturan pemerintah No 71 Tahun 2010 pasal 1 ayat (8) bahwa yang dimaksud SAP berbasis akrual adalah standar akuntansi pemerintahan yang mengakui pendapatan, beban, aset, utang dan ekuitas dalam pelaporan finansial berbasis akrual, serta mengakui pendapatan, belanja, dan pembiayaan dalam pelaporan pelaksanaan anggaran berdasarkan basis yang diterapkan dalam APBN/APBD.

Dinas Pekerjaan Umum Bina Marga dan Tata Ruang Provinsi Sumatera Selatan sebagai salah satu entitas pelapor dalam penyajian laporan keuangan pada tahun 2014 masih menggunakan PP 24 tahun 2005 berdasarkan Accrual Ke Kas. Sementara pada akhir 2015 Dins Pekerjaan Umum Bina Marga dan Tata Ruang Provinsi Sumatera Selatan telah mulai menerapkan PP Tahun 712010 tentang laporan keuangan berdasarkan akrual meskipun tidak sepenuhnya dengan menyiapkan sumber daya manusia yang kompeten, SIMDA yang merupakan perangkat dukungan dan Organisasi Komitmen. Laporan keuangan telah disajikan pada tahun 2015 meliputi laporan realisasi anggaran, neraca dan laporan arus kas. Laporan keuangan adalah:

Laporan Realisasi Anggaran

Laporan Realisasi Anggaran mengungkapkan kegiatan keuangan pemerintah pusat/daerah yang menunjukkan ketaatan terhadap APBN/APBD. Laporan Realisasi Anggaran menyajikan ikhtisar sumber, alokasi dan penggunaan sumber daya ekonomi yang dikelola oleh pemerintah pusat/daerah dalam satu periode pelaporan.

Neraca

Neraca menggambarkan posisi keuangan suatu entitas pelaporan mengenai aset,kewajiban, dan ekuitas dana pada tanggal tertentu.

$>\quad$ Laporan Arus Kas

Laporan Arus Kas menyajikan informasi kas sehubungan dengan aktivitas operasi, investasi, pendanaan, dan transitoris yang menggambarkan saldo awal, penerimaan, pengeluaran, dan saldo akhir kas pemerintahpusat/daerah selama periode tertentu. Unsur yang dicakup dalam Laporan Arus Kas terdiri dari penerimaan dan pengeluaran kas.

\section{2) Proses Realisasi Anggaran di Dinas PU Bina Marga dan Tata Ruang Provinsi Sumatera Selatan}

Setelah keluar Surat Perintah Pencairan Dana (SP2D) dari Kantor BPKAD kemudian bagian keuangan Dinas PU Bina Marga dan Tata Ruang Provinsi Sumatera Selatan mengeluarkan kwitansi panjar yang di tandatangan oleh Bendahara Pengeluaran dan Bendahara Pengeluaran Pembantu yang akan diserahkan ke masing-masing Pemegang Uang Muka Kerja (PUMK) selanjutnya diserahkan ke Pejabat Pembuat Komitmen (PPK) untuk digunakan sesuai rencana belanja yang akan direalisasikan. 


\section{Gambar Bagan Arus}

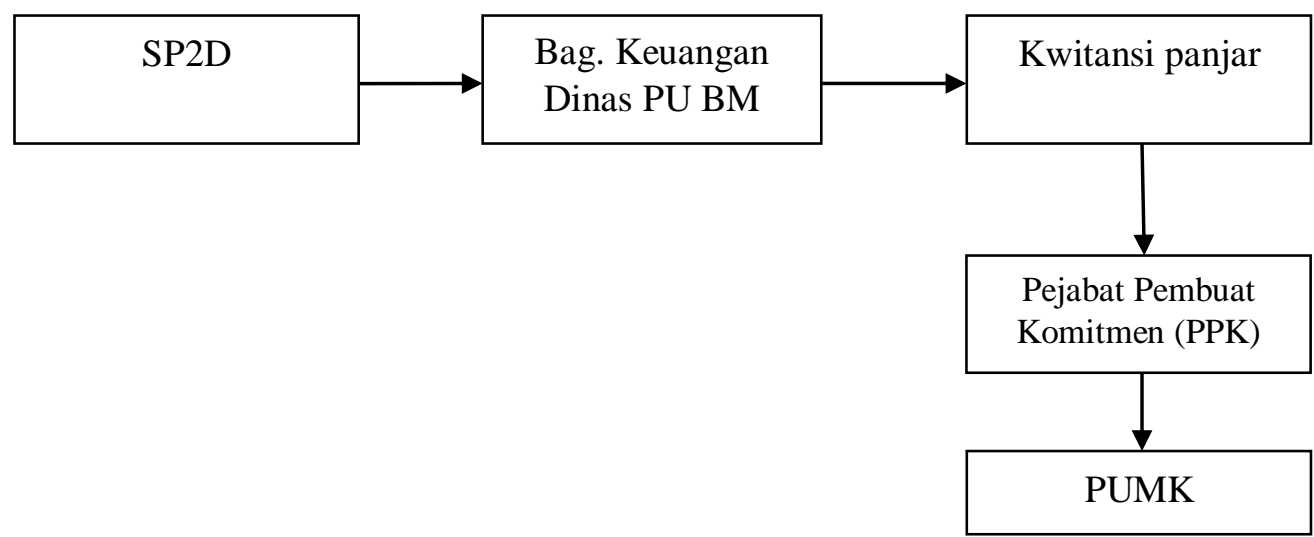

\section{3) Pencatatan dan Pembukuan Laporan Keuangan di Dinas PU Bina Marga dan Tata Ruang Provinsi Sumatera Selatan}

Pencatatan dan Pembukuan dibuat diinput oleh Bendahara Pengeluaran Pembantu total kwintansi seluruh belanja dicatat di Buku Pembantu Panjar yang ditandatangani oleh Kuasa Pengguna Anggaran (KPA), Bendahara Pengeluaran dan bendahara Pengeluaran Pembantu selanjutnya seluruh kwintansi per item dicatat di Buku Kas Umum (BKU) beserta nilai seluruh pajak yang dipotong yang ditandatangan oleh Pejabat Pembuat Komitmen (PPK) dan Bendahara Pengeluaran Pembantu (BPP). Setelah dicatat di buku pembantu panjar dan buku kas umum baru dibuat neraca dan laporan realisasi anggaran yang ditandatangan oleh bendahara pengeluaran pembantu.

\section{Gambar Bagan Arus}

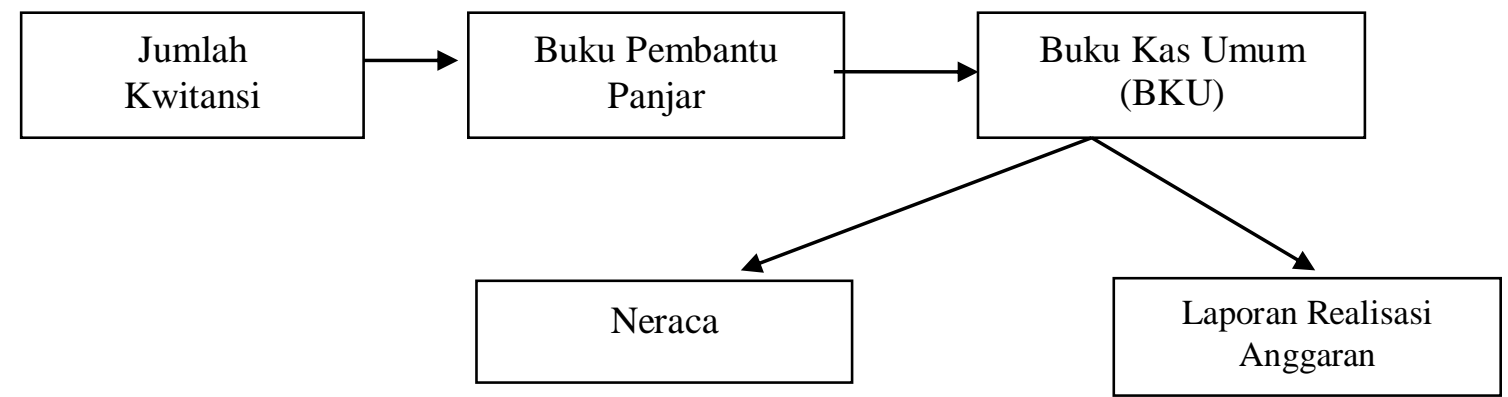

\section{4) Alat Yang Digunakan Dalam Menerapkan Standar Akuntansi Pemerintahan (SAP) Berbasis Akrual}

Dalam rangka mendukung penerapan basis akuntansi akrual, penggunaan teknologi yang andal sangat diperlukan guna mendukung keberhasilan pengolahan data baik pada masa transisi maupun masa penerapan basis akrual secara penuh. Penggunaan alat yang memadai dalam menerapkan standar akuntansi berbasis akrual diarahkan untuk mengembangkan sistem akuntansi dalam rangka mempermudah pegawai dalam menginput dan mengolah data keuangan yang akan disajikan didalam laporan keuangan.

Dinas PU Bina Marga dan Tata Ruang Provinsi Sumatera Selatan telah 
menyiapkan sistem untuk membuat laporan keuangan yang diberikan oleh pusat. Aplikasi bernama SIMDA merupakan Sistem Informasi Manajemen Daerah yang berbasis akrual. Aplikasi SIMDA dapat diimplementasikan menggunakan teknologi, client/server dari penyusunan anggaran dan pertanggungjawaban keuangan yang baik. Sebelumnya, aplikasi SIMDA yang digunakan adalah SIMDA versi 2.7.1 Berbasis Kas Menuju Akrual Sedangkan pada tahun 2015 telah menggunakan SIMDA versi 2.7.7 Berbasis Akrual. Dengan adanya aplikasi SIMDA versi 2.7.7 maka pengelolaaan laporan keuangan akan lebih mudah dilaksanakan.

\section{E. PEMBAHASAN}

1) Analisis Penerapan Standar Akuntansi Pemerintah Berdasarkan PP No. 71 Tahun 2010 Pada Dinas Pekerjaan Umum Bina Marga dan Tata Ruang Provinsi Sumatera Selatan

Proses pengajuan dan pencaiaran dana di Dinas PU Bina Marga dan Tata Ruang Provinsi Sumatera Selatan berdasarkan peraturan pemerintah daerah masing-masing dengan melampirkan semua berkas lampiran-lampiran yang berlaku pada peraturan daerah tersebut.

Realisasi anggaran di Dinas PU Bina Marga Provinsi Sumatera Selatan tidak berdasarkan PP No.71 Tahun 2010 karena di Dinas PU Bina Marga dan Tata Ruang Provinsi Sumatera Selatan pendapatan di kas tidak digunakan untuk membayarkan utang seperti yang tercantum didalam peraturan PP No.71 Tahun 2010 karena setiap akhir tahun antara rencana dan realisasi harus habis terserap sampai $100 \%$ sehingga tidak ada dana yang terdapat didalam kas bendahara. Hal ini dikarenakan jika seandainya masih terdapat sisa atau kelebihan anggaran pada tahun yang bersangkutan, maka besar kemungkinan akan diadakan pengurangan dana pada tahun berikutnya, sesuai dengan mata anggaran yang mengalami sisa anggaran. Kondisi seperti ini tentunya sangat tidak baik untuk kelanjutan suatu kegiatan, maka untuk mengefektifkan suatu kegiatan maka dana yang tersedia juga harus sesuai dengan besarnya anggaran kegiatan.

Pencatatan dan pembukuan laporan keuangan di Dinas PU Bina Marga dan Tata Ruang Provinsi Sumatera Selatan Tahun Anggaran 2014 tidak berdasarkan PP No. 71 Tahun 2010 karena didalam pencatatan pembukuan di Dinas PU Bina marga dan Tata Ruang hanya dibuat dalam bentuk necara dan laporan realisasi keuangan saja sedangkan dalam PP No. 71 Tahun 2010 komponen laporan keuangan pokoknya terdiri dari Laporan Anggaran, Laporan Realisasi Anggaran, Laporan Perubahan Saldo Anggaran Lebih, Neraca, Laporan Operasional, Laporan Arus Kas, Laporan Perubahan Ekuitas dan Catatan atas Laporan Keuangan.

Alat yang digunakan dalam menerapkan Standar Akuntansi Pemerintahan (SAP) Berbasis Akrual di Dinas PU Bina Marga dan Tata Ruang Provinsi Sumatera Selatan Tahun Anggaran 2014 masih menggunakan sistem manual dengan melakukan pencatatan pembukuan di buku pengawas kredit belum diterapkanya aplikasi online seperti yang diterapkan di PP No. 71 tahun 2010 yaitu aplikasi SIMDA yang digunakan adalah SIMDA versi 2.7.1 Berbasis Kas Menuju Akrual Sedangkan pada tahun 2015 telah menggunakan SIMDA versi 2.7.7 Berbasis Akrual.

\section{2) Komitmen Organisasi}

Salah satu penyebab kelemahan penyusunan Laporan Keuangan pada beberapa Kementrian/lembaga adalah lemahnya komitmen pimpinan Satuan Kerja Perangkat Daerah (SKPD) penerima dana Dekonsentrasi/Tugas Pembantuan. 
Kasubbag Keuangan mengungkapkan bahwa pimpinan sangat mendukung penerapan basis akrual yang telah ditetapkan oleh pemerintah. Diharapkan penerapan standar berbasis akrual ini dapat dilaksanakan dengan baik sehingga laporan keuangan yang akan disajikan dapat transparan dan akuntabel.

Komitmen Dinas PU Bina Marga dan Tata Ruang Provinsi Sumatera Selatan dalam menerapkan basis akrual untuk pelaporan keuangan sangat mendukung peraturan ini dapat terlaksana dengan baik meskipun pada prakteknya masih belum dapat terlaksana dengan baik karena terdapat beberapa kendala yang harus dihadapi. Akan tetapi, Dinas PU Bina Marga dan Tata Ruang Provinsi Sumatera Selatan berkomitmen untuk terus berusaha belajar dan berlatih dalam penerapan SAP berbasis akrual dalam pelaporan keuangan. Adapun bentuk perbaikan yang dilakukan oleh Dinas PU Bina Marga dan Tata Ruang Provinsi Sumatera Selatan terhadap para pegawainya antara lain yaitu dengan cara mengikuti pelatihanpelatihan, diklat dan sosialisasi yang diadakan oleh BPKAD yang berkaitan dengan penerapan Sistem Informasi Manajemen Daerah (SIMDA).

\section{3) Rencana Strategis Dalam Penerapan Standar Akuntansi Berbasis Akrual}

Dalam menerapkan PP No.71 tahun 2010 dan untuk memenuhi ketentuan Pasal 10 ayat (2) Permendagri No.64 Tahun 2013 tentang Penerapan SAP Berbasis Akrual Pada Pemerintah Daerah yang mengharuskan penerapan SAP Berbasis Akrual pada pemerintah daerah paling lambat mulai Tahun 2015, Dinas PU Bina Marga dan Tata Ruang Provinsi Sumatera Selatan menyadari sepenuhnya bahwa penerapan SAP dalam menyajikan laporan keuangan di setiap kementerian/lembaga maupun daerah sangat wajib segera dilaksanakan. Adanya audit yang akan dilakukan oleh BPK berperan terhadap opini yang akan diberikan BPK atas laporan keuangan. Dasar BPK melakukan audit adalah SAP, sehingga penyusunan laporan keuangan harus berprinsip pada transparansi dan akuntabilitas. Dinas PU Bina Marga dan Tata Ruang Provinsi Sumatera Selatan yang dalam hal ini penggunaan aplikasi SIMDA keuangan yang sudah mengakomodir sistem akuntansi pemerintahan berbasis akrual, diharapkan dapat menunjang kesiapan untuk lebih mapan dan mantap dalam menerapkan SAP Berbasis Akrual dalam menyajikan laporan keuangan. Dengan hal ini, Dinas PU Bina Marga dan Tata Ruang Provinsi Sumatera Selatan menunjukan komitmen dan apresiasi nyata dalam melaksanakan dan/atau menerapkan peraturan pemerintah untuk menerapkan SAP. Berbasis Akrual yang diharapkan dapat menghasilkan laporan keuangan yang lebih akuntabel dan transparan.

\section{G. KESIMPULAN DAN SARAN}

1) Kesimpulan

Berdasarkan hasil pembahasan penelitian ini, maka ditarik kesimpulan bahwa:

a) Penerapan Standar Akuntansi Pemerintahan di Dinas PU Bina Marga dan Tata Ruang Provinsi Sumatera Selatan pada Tahun Anggaran 2018 belum menerapkan PP No. 71 Tahun 2010 karena dalam pencatatan dan pembukuan laporan keuangan cuma terdapat komponen laporan realisasi anggaran, necara dan laporan arus kas sedangkan komponen laporan keuangan yg berdasarkan PP No. 71 Tahun 2010 yang lainnya belum ada dan SAP di Dinas PU Bina Marga dan Tata Ruang belum berbasis akrual karena transaksi dicatat pada saat terjadinya transaksi uang masuk dan keluar harus sama antara yang diterima dengan yang dikeluarkan pada saat terjadinya transaksi. 
b) Sistem informasi pada Dinas PU Bina Marga dan Tata Ruang Provinsi Sumatera Selatan telah menggunakan SIMDA Versi 2.7.7 cukup membantu dalam penerapan pelaporan keuangan.

c) Dinas PU Bina Marga dan Tata Ruang Provinsi Sumatera Selatan berkomitmen untuk menerapkan pelaporan keuangan berbasis akrual dengan melalui pelatihan-pelatihan dalam bentuk diklat dan sosialisasi yang diadakan oleh BPKAD yang berkaitan dengan penerapan Sistem Informasi Manajemen Daerah (SIMDA).

\section{2) Saran} berikut :

Berdasarkan kesimpulan diatas maka peneliti menyarankan hal-hal sebagai

a) Hendaknya Dinas PU Bina Marga dan Tata Ruang Provinsi Sumatera Selatan menerapkan PP No.71 Tahun 2010 pada penyusunan laporan keuangan. Setiap komponen-komponen laporan keuangan harus diterapkan secara lengkap agar mempermudah dalam proses pemeriksaan laporan keuangan.

b) Penggunaa aplikasi SIMDA harus lebih dioptimalkan lagi,, baik oleh penyusun maupun pengguna, agar laporan keuangan yang dihasilkan lebih akurat dan lebih handal.

c) Hendaknya Dinas PU Bina Marga dan Tata Ruang Provinsi Sumatera Selatan, selalu melakukan penyempurnaan / perbaikan dalam penerapan PP No.71 tahun 2010 dalam penyusunan laporan keuangan, sehingga penerapan Akuntansi Pemerintahan berbasis akrual pas diimplementasikan dalam struktur pemerintahan.

\section{DAFTAR PUSTAKA}

Bastian Indra, 2010, Akuntansi SektorPublik Suatu Pengantar, Edisi Ketiga, Erlangga: Jakarta.

Mulyanto, Agus, 2009, Sistem Informasi Konsep dan Aplikasi, Pustaka Pelajar: Yogyakarta.

Mardiasmo, 2018, Akuntansi Sektor Publik, ANDI: Yogyakarta.

Moleong, Lexy, 2010, Metodologi Penelitian Kualitatif, Penerbit PT Remaja Rosdakarya : Bandung

Mustakini, Jogiyanto Hartono, 2009, Sistem Informasi Teknologi, Andi Offset: Yogyakarta.

Peraturan Menteri Dalam Negri Nomor 13 Tahun 2006 Tentang Pedoman Pengelolaan Keuangan Daerah.

Peraturan Pemerintah Nomor 8 Tahun 2006 tentang Pelaporan Keuangan dan Kinerja Instansi Pemerintah. 
Peraturan Pemerintah Nomor 71 Tahun 2010, Standar Akuntansi Pemerintah (SAP), Indonesia.

Renyowijoyo, Muindro, 2010,Akuntansi Sektor Publik - Organisasi Non Laba. Edisi Kedua, Mitra Wacana Media : Jakarta.

Semiawa, C. R. (2010). Metode Penelitian Kualitatif Jenis, Karakteristik dan Keunggulannya. Grasindo: Jakarta

Silalahi, U, 2010, Metode Penelitian Sosial, Unpar Press: Bandung.

Sugiyono, 2017, Memahami Penelitian Kualitatif, Alfabeta: Bandung.

Widjajarso, Bambang,2008, Penerapan Basis Akrual Pada Akuntansi Pemerintah Indonesia: Sebuah Kajian Pendahuluan.

Yakub, 2012, Pengantar Sistem Informasi, Graha Ilmu: Yogyakarta. 